\title{
Workshop dan Bimbingan Teknis Tata Cara Perencanaan serta Penganggaran Aktivitas Penggunaan Dana Desa
}

Dwi Indah Lestari ${ }^{1}$, Muhammad Ridwan Mustafa ${ }^{2}$, Muhammad Anggionaldi ${ }^{2}$

1,2 Universitas Jenderal Achmad Yani, Indonesia

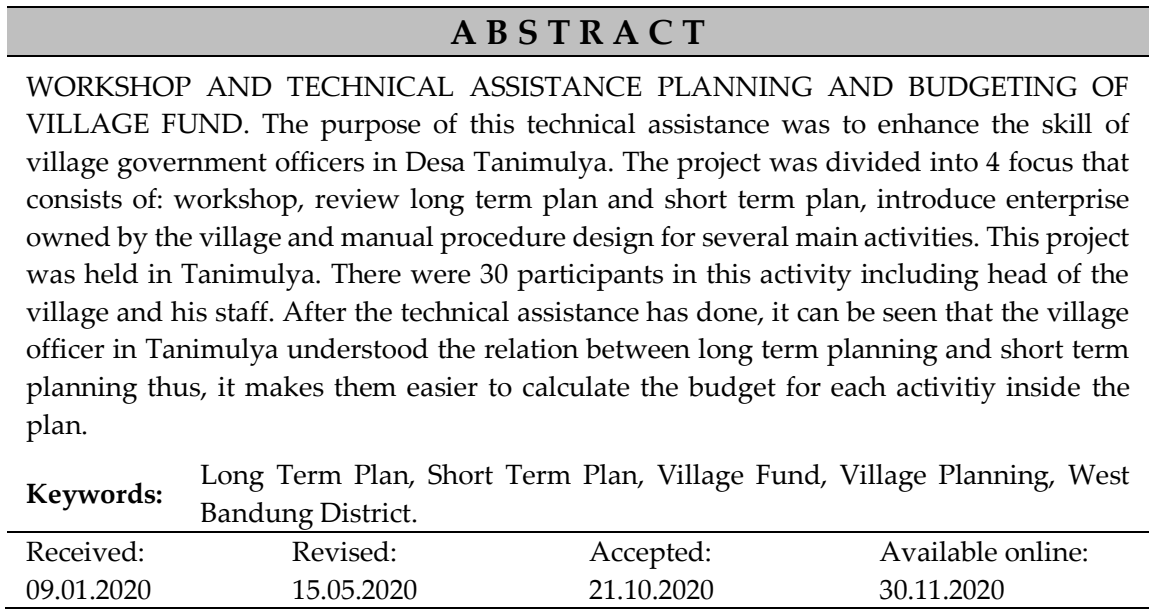

Suggested citation:

Lestari, D. I., Mustafa, M. R., \& Anggionaldi, M. (2020). Workshop dan bimbingan teknis tata cara perencanaan serta penganggaran aktivitas penggunaan dana desa. Jurnal Pengabdian Pada Masyarakat, 5(4), 1015-1024. https://doi.org/10.30653/002.202054.391

Open Access I URL: http://ppm.ejournal.id/index.php/pengabdian/article/view/391

${ }^{1}$ Corresponding Author: Program Studi Akuntansi, FEB Universitas Jenderal Achmad Yani; Jl. Terusan Jenderal Sudirman, Cimahi, Indonesia. Email: dwi.lestari@unjani.ac.id 


\section{PENDAHULUAN}

Dengan diberlakukannya UU Nomor 6 Tahun 2014, desa memiliki peluang untuk mengelola kepentingan dan kebutuhan masyarakat desa secara swadaya. Dengan adanya pelimpahan wewenang yang cukup besar tersebut, desa berkewajiban untuk menerapkan prinsip akuntabilitas dalam tata pemerintahannya. Untuk itu desa diharuskan mempertanggungjawabkan seluruh aktivitasnya kepada masyarakat desa dan Pemerintah Pusat.

Dalam tahap perencanaan dan penganggaran, Pemerintah Desa diharuskan untuk meminta pertimbangan dari masyarakat desa yang diwakili oleh Badan Permusyawaratan Desa (BPD) sehingga rencana pembangunan desa akan sesuai dengan kebutuhan masyarakat desa. Selain pertimbangan BPD, beberapa desa meminta masukan dari semua Rukun Warga (RW) yang ada dalam desa tersebut.

Salah satu desa yang berada di sekitar Universitas Jenderal Achmad Yani adalah desa Tanimulya yang terletak di Kecamatan Ngamprah, Kabupaten Bandung Barat. Desa ini terdiri dari 25 Rukun Warga dan 163 Rukun tetangga, dengan luas sebesar 220,7 Km2. Desa Tanimulya merupakan salah satu desa berprestasi dan meraih banyak penghargaan antara lain: meraih peringkat ke dua desa terbaik di Provinsi Jawa Barat. Penghargaan ini membuat desa Tanimulya menjadi desa percontohan bagi desa lain. Akan tetapi menurut hasil review yang dilakukan oleh BPKP (Badan Pengawasan Keuangan dan Pembangunan) Perwakilan Bandung, Desa Tanimulya masih mengalami kesulitan dalam merencanakan dan menganggarkan aktivitas yang didukung oleh dana desa. Berdasarkan hasil wawancara dengan pihak BPKP serta survey lapangan ditemukan bahwa selain kemampuan tata kelola Pemerintah Desa yang kurang baik, kendala yang ditemukan di lapangan adalah kurangnya kemampuan Sumber Daya Manusia (SDM), belum adanya prosedur serta sarana dan prasarana dalam pengelolaan keuangan serta kurangnya pengawasan dari masyarakat desa. Hal ini menyebabkan proses pembelanjaan desa terkendala. Oleh karena itu dibutuhkan percepatan peningkatan kualitas akuntabilitas keuangan negara bagi Pemerintah Desa, dimulai dari transparansi rencana dan anggaran kerja atas aktivitas yang didanai oleh Dana Desa.

Hingga saat ini aparat desa hanya mengandalkan pelatihan yang dilaksanakan oleh BPKP serta masukan dari pendamping desa. Akan tetapi pelatihan tersebut tidak dilakukan secara berkesinambungan sehingga pada pelaksanaannya terjadi banyak kesalahan dalam teknis pertanggungjawaban aktivitas desa. Untuk itu, Jurusan Akuntansi - Fakultas Ekonomi dan Bisnis Universitas Jenderal Achmad Yani berinisiatif untuk melakukan evaluasi, pelatihan dan pendampingan perencanaan aktivitas penggunaan dana desa yang akan dilakukan secara bertahap, dimulai dari tahap evaluasi perencanaan aktivitas, penganggaran serta pelaporan aktivitas. Ketiga tahap tersebut akan dilakukan dengan memanfaatkan SIMKEUDES (Sistem Keuangan desa). Dalam prosesnya, evaluasi dan pelatihan tersebut dilaksanakan bersama dengan pihak BPKP. Hal ini ditujukan agar kegiatan pelatihan dan pendampingan berjalan sesuai dengan peraturan yang berlaku. Seluruh kegiatan tersebut di laksanakan di desa Tanimulya.

Target dalam program Pengabdian Pada Masyarakat yang dilaksanakan pada tahun 2019 adalah untuk (1) meningkatkan keahlian para pengelola dana desa dalam 
menyelenggarakan perencanaan aktivitas penggunaan dana desa, (2) meningkatkan pengetahuan dan pemahaman para pengelola dana desa dalam menyusun perencanaan aktivitas penggunaan dana desa dan tata kelola keuangan desa yang baik dan (3) membantu menciptakan perencanaan penggunaan dana desa yang partisipatif, terintegrasi dan selaras dengan perencanaan daerah.

\section{METODE}

Kegiatan pengabdian pada masyarakat ini dilakukan dengan pendekatan workshop dan technical assistance serta pendampingan selama 3 bulan setelah workshop diberikan. Menurut Soler, Cocozza, dan Henry (2013) bimbingan teknis adalah proses untuk membangun suatu cara yang kreatif dan efektif dalam mendukung organisasi, system maupun individu untuk menilai kebutuhan dan halangan dalam mencapai tujuan, membangun rencana strategis untuk jangka panjang dan membuat pendekatan inovatif untuk berbagai masalah dengan isu yang kompleks. Metode ini dipilih sebagai metode yang tepat dengan pertimbangan sebagai berikut: (1) Aparat desa belum mendapatkan ilmu yang dibutuhkan dalam merancang dan membuat anggaran kegiatan yang sesuai dengan ketentuan berdasarkan hukum yang berlaku. (2) Belum adanya solusi atas permasalahan perencanaan dan penganggaran dana desa. (3) Belum optimalnya Badan Usaha Milik Desa (BumDes) serta (4) Belum adanya SOP tertulis untuk beberapa aktivitas inti yang dilakukan secara berulang.

Tabel 1. Daftar Kegiatan, Peserta dan Metode

\begin{tabular}{lllll}
\hline No & Kegiatan & Identifikasi Peserta & Jumlah & Metode \\
\hline 1 & Workshop dan & Kepala Desa & 1 Orang & \\
& Pengenalan & Sekertaris Desa & 1 Orang & \\
& konsep BumDes & Bendahara & 1 Orang & \\
& & Staff Keuangan & 3 Orang & Workshop \\
& & Badan Permusyawaratan Desa & 4 Orang & \\
& & Perwakilan BumDes & 4 Orang & \\
& & Perwakilan warga Tanimulya & 8 Orang & \\
& & Sesepuh Desa & 1 Orang & \\
\hline & Jumlah & & 23 Orang & \\
\hline 2. & Bimbingan & Kepala Desa & 1 Orang & \multirow{2}{*}{ Bimbingan } \\
& Teknis Review & Sekertaris Desa & 1 Orang & Teknis \\
& RPJM Desa dan & & \multicolumn{2}{c}{} \\
& RKP Desa & & 2 Orang & \\
\hline & Jumlah & & 1 Orang & \\
\hline 3. & Pendampingan & Bendahara & 2 Orang & Pendampingan \\
& proses & Staff Keuangan & 1 Orang & \\
& penganggaran & Sekertaris Desa & 4 Orang & \\
\hline & Jumlah & & 1 Orang & \multirow{2}{*}{ Bimbingan } \\
\hline 4. & Pendampingan & Sekertaris Desa & 2 Orang & Teknis \\
& Perancangan & Staff Desa & 3 Orang & \\
& SOP & & & \\
\hline & Jumlah & & & \\
\hline
\end{tabular}


Proses kegiatan Pengabdian Masyarakat dilaksanakan secara berkala, yang terdiri atas: (A) proses pembekalan berupa workshop, (B) Bimbingan teknis review RPJM Desa dan RKP desa (C) pendampingan proses penganggaran kedalam RKP dan proses input anggaran kedalam system, (D) pengenalan konsep Badan Usaha Milik Desa (BumDes) dan (E) bimbingan teknis perancangan SOP kegiatan desa. Detail peserta untuk setiap kegiatan dapat dilihat pada Tabel 1.

\section{HASIL DAN PEMBAHASAN}

Sebelum pembekalan ke desa Tanimulya, seluruh tim dosen yang terlibat mendapatkan pelatihan dari BPKP kantor Perwakilan Bandung mengenai Dana Desa dan SIMKEUDES. Hal ini dimaksudkan agar seluruh ilmu yang diberikan kepada desa telah sesuai dengan peraturan terkini yang berlaku dan tim dapat memahami persoalan desa dengan lebih baik sehingga dapat memberikan rekomendasi yang tepat kepada pemerintah desa.

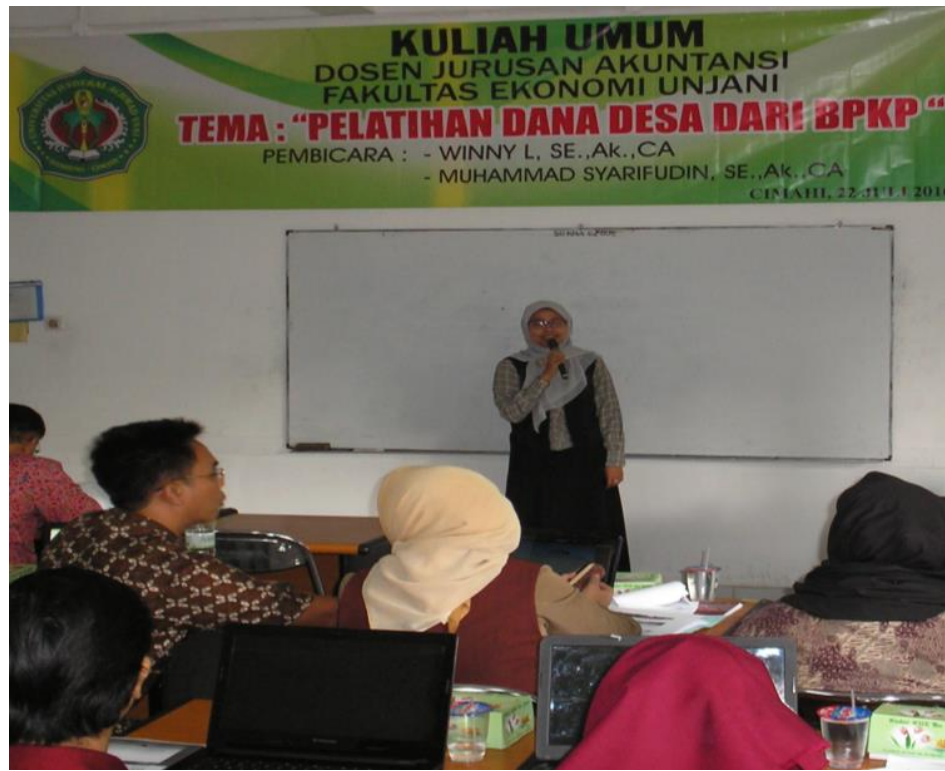

Gambar 1. Aktivitas Pelatihan Dana Desa dari BPKP

\section{Workshop}

Setelah pelatihan dilakukan rangkaian Pengabdian Pada Masyarakat dimulai dengan proses pembekalan berupa workshop yang dilaksanakan pada bulan Agustus 2019. Materi Workshop diberikan oleh tim dosen kepada Pemerintah Desa, BPD, perwakilan BumDes, dan perwakilan warga Tanimulya. Dalam Workshop tersebut, antusiasme dan ide dari aparat desa maupun warga dapat tertampung yang pada akhirnya memperkaya proses bimbingan teknis.

Menurut Berlian Ramadana dan Ribawanto (2013) BumDes dapat disesuaikan dengan kebutuhan dan potensi yang dimiliki oleh desa. Beberapa BumDes telah ada di lingkungan Desa Tani Mulya, namun keberadaannya belum berjalan secara maksimal. 
Berdasarkan hasil diskusi dalam workshop ditemukan beberapa permasalahan diantaranya adalah permodalan awal untuk pengelolaan BumDes, Business plan BumDes dan rendahnya komitmen Pemerintah Desa

Permodalan awal pengelolaan BumDes merupakan salah satu masalah yang terungkap didalam workshop. Terdapat kekhawatiran oleh pejabat dan pimpinan BPD untuk menggunakan Dana Desa sebagai modal awal untuk pengelolaan BumDes. Kekhawatiran ini disebabkan belum ada informasi yang pasti mengenai payung hukum penggunaan dana desa untuk diperuntukkan sebagai modal awal pengelolaan Badan Usaha Milik Desa (BumDes). Peraturan Menteri Keuangan Republik Indonesia No.93/PMK.07/2015 tentang Tata Cara Pengalokasian, Penyaluran, Penggunaan, Pemantauan, dan Evaluasi Dana Desa, juga tidak menyebutkan secara eksplisit penggunaan dana desa diperbolehkan sebagai modal awal untuk pendirian BumDes (Pemerintah Republik Indonesia, 2015b)

Oleh karena itu, diperlukan informasi tambahan yang mengungkapkan secara jelas mengenai pemanfaatan dana desa yang dapat diperuntukkan sebagai modal Badan Usaha Milik Desa. Berdasarkan Peraturan Menteri Desa No.5 Tahun 2015 tentang Penetapan Prioritas Penggunaan Dana Desa dalam pasal 5 (c) menyebutkan prioritas penggunaan dana desa dialokasikan untuk mencapai tujuan pembangunan desa yakni peningkatan kesejahteraan masyarakat desa dan kualitas hidup manusia serta penanggulangan kemiskinan salah satunya melalui pengembangan potensi ekonomi lokal. Mendasarkan pada pasal 5 (c) prioritas penggunaan dana desa harus sejalan dengan pencapaian target RPJM Desa dan RKP Desa setiap tahunnya yang meliputi pendirian dan pengembangan BumDes (Pemerintah Republik Indonesia, 2015a).

Dari kerangka hukum Peraturan Menteri Desa, dapat diketahui bahwa penggunaan dana desa untuk modal awal pendirian BumDes diperkenankan secara undang-undang dan tidak menyalahi aturan yang ada. Permasalahan berikutnya yang terungkap terkait BumDes yakni masih minimnya pengetahuan pengelola BumDes terkait Bussiness Plan. Para pengelola BumDes di desa Tani Mulya belum memiliki kesiapan dalam mengelola dana yang diperuntukkan sebagai modal BumDes.

Hasil diskusi dalam workshop menghasilkan pemetaan potensi ekonomi lokal yang dapat dimanfaatkan sebagai sumber-sumber pendapatan asli desa cukup menjanjikan. Saat ini di lingkungan Desa Tani Mulya telah berdiri setidaknya 6 (enam) lokasi perumahan diantaranya adalah Bumi Pakusarakan, Perumahan Tani Mulya, Puri Cipageran 2, Kelapa Gading, Cidahu Regency, Blok Anggrek, Griya Asri Pakusarakan dan Permata Cimahi. Maraknya perumahan yang berdiri tidak lain karena akses dari arah pembangunan pemukiman tidak lagi terpusat di kota, tetapi beralih ke daerah penyangga bandung seperti Cimahi dan Bandung Barat. Peluang ini dapat dimanfaatkan oleh Pemerintahan Desa untuk menambah sumber-sumber penghasilan mereka dengan memanfaatkan BumDes sebagai lembaga institusional dan professional untuk mengelola dan memfasilitasi dari kebutuhan komplek perumahan tersebut. Pengelolaan sanitasi/kebersihan/sampah bisa dialihkan ke Pemerintahan Desa dengan memungut pembayaran iuran sampah kepada masyarakat perumahan.

Selain itu, aspek lain yang bisa dikelola menjadi sumber-sumber penghasilan desa, yakni pengelolaan pasar. Desa dapat menunjuk BumDes untuk mengelola retribusi pasar seperti tempat parker, retribusi kebersihan sampah. 
Pengembangan potensi ekonomi lokal dengan tidak mengindahkan kearifan lokal masyarakat desa tani mulya yang lekat dengan pertanian dan perkebunan, masyarakat perlu di ajak untuk memanfaatkan potensi sumber daya lokal untuk membuat kerajinan dan pengelolaan pemasaran nya dikelola oleh BumDes. Pada akhirnya BumDes dapat menjadi pionir yang menjadikan desa mandiri secara keuangan dan tidak bergantung pada sumber-sumber pendapatan yang berasal dari alokasi dana desa dan APBD.

Permasalahan terakhir yang terungkap adalah rendahnya komitmen Pemerintah Desa. Rendahnya komitmen Pemerintah Desa disebabkan karena saat ini Dana Desa difokuskan pada pembangunan fasilitas fisik (sarana dan prasarana). RKP yang disusun belum menganggarkan pengalokasian Dana Desa untuk modal awal BumDes. Maka dapat disimpulkan bahwa Pemerintah Desa Tanimulya belum berkomitmen untuk meningkatkan pendapatan desa melalui BumDes.

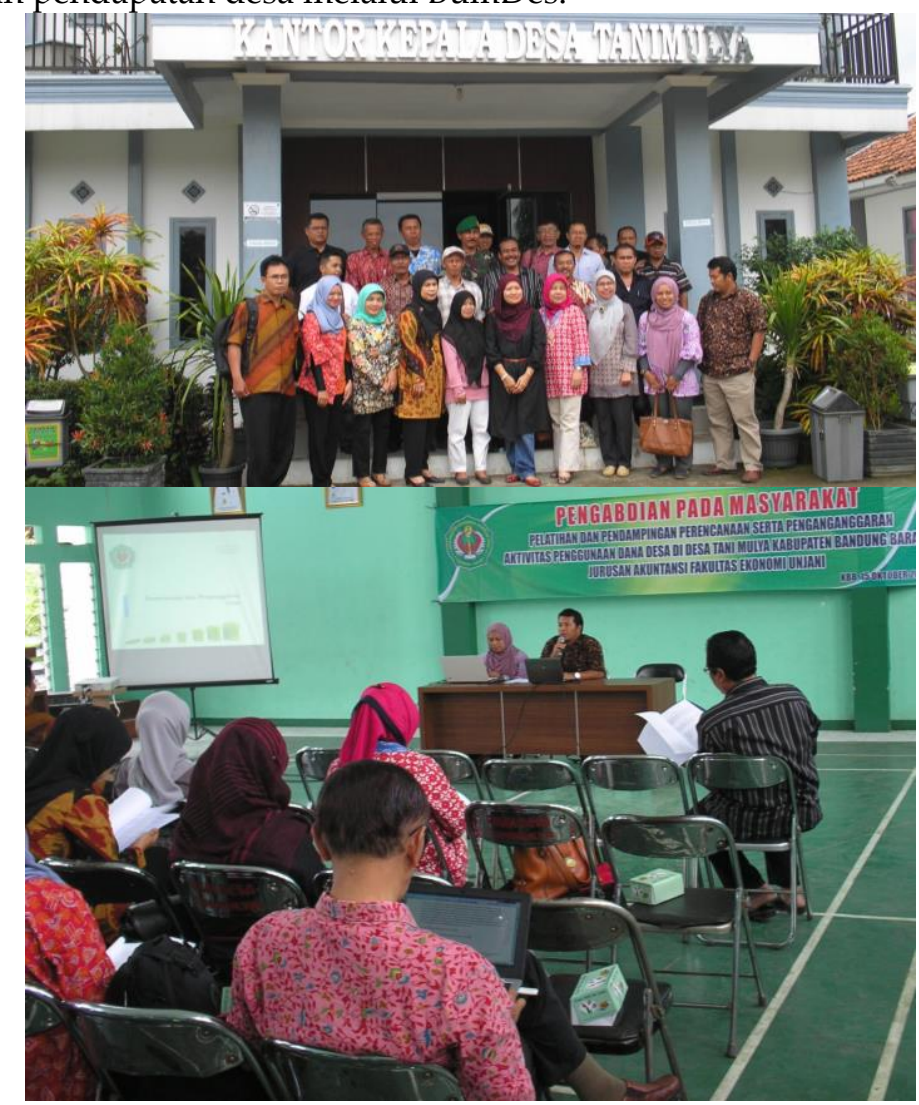

Gambar 2. Workshop

Bimtek Review RPJM Desa (Rencana Pembangunan Jangka Menengah) dan RKP (Rencana Kerja Pemerintah)

Pemerintah Desa menyusun perencanaan pembangunan desa sesuai dengan kewenangannya dengan mengacu pada perencanaan pembangunan kabupaten/kota. Perencanaan Pembangunan Desa meliputi RPJM Desa dan RKP Desa yang disusun secara berjangka dan ditetapkan dengan Peraturan Desa. RPJM Desa dirancang untuk jangka waktu 6 (enam) tahun sedangkan Rencana Pembangunan Tahunan Desa atau RKP Desa dirancang untuk jangka waktu 1 (satu) tahun. RKP Desa merupakan 
penjabaran dari RPJM Desa, untuk itu perlu diperhatikan keselarasan RKP Desa dengan RPJM Desa. Berdasarkan Permendagri Nomor 114 Tahun 2014 tentang Pedoman Pembangunan Desa, RKP Desa hanya bisa diubah apabila terjadi peristiwa khusus ataupun perubahan mendasar atas kebijakan Pemerintah (Menteri Dalam Negeri Republik Indonesia, 2014).

Berdasarkan hasil review kesesuaian RKP Desa tahun 2018 dan 2019 dengan RPJM Desa ditemukan bahwa sebagian besar rencana kerja pemerintah Desa Tanimulya telah dilaksanakan sesuai dengan RPJM Desa. Akan tetapi ditemukan beberapa kegiatan yang dalam pelaksanaannya tidak sesuai dengan RPJM Desa. Hal ini disebabkan karena ada beberapa aktivitas yang dianggap cukup mendesak, sehingga aktivitas tersebut dilaksanakan walaupun tidak tertuang dalam RPJM Desa, seperti pengadaan kendaraan operasional dan lomba desa. Berdasarkan hasil observasi dan wawancara dengan pemerintah Desa Tanimulya, ditemukan bahwa target wilayah aktivitas yang dilaksanakan seringkali tidak sesuai dengan target wilayah yang tercantum dalam RPJM Desa, dikarenakan pertimbangan di lapangan dimana wilayah tersebut dinilai mendesak.

Sama halnya dengan hasil review di tahun 2018 dan 2019, dalam draft RKP Desa tahun 2020 ditemukan beberapa kegiatan yang sebelumnya tidak tercantum di dalam RPJM Desa yaitu penyelenggaraan musyawarah desa dan pembinaan imam masjid. Karena tambahan kegiatan tersebut dianggap penting dan nilai anggarannya tidak material, maka tim dosen menilai kedua kegiatan tersebut dapat dilaksanakan walaupun tidak masuk kedalam RPJMDes. Hasil review bersama dengan Kepala Desa dan Sekertaris Desa menyadarkan aparat Desa bahwa seluruh kegiatan yang dilakukan harus selaras.

\section{Pendampingan Proses Penganggaran kedalam RKP dan Proses Input Anggaran ke Dalam Sistem}

Menurut Suralim, Tarigan, \& Hatane (2018) anggaran adalah suatu alat bagi manajemen untuk mengalokasikan sumber daya organisasi yang terbatas dengan tujuan agar organisasi dapat meraih tujuannya. Anggaran merupakan salah satu alat pengendalian manajemen yang umum digunakan oleh manajer untuk memastikan rencana strategis berjalan dengan baik (Anthony \& Govindarajan, 2006; Blay, Douthit, \& Fulmer, 2019). Perlu diperhatikan bahwa anggaran di sektor public akan berbeda dengan anggaran di sektor privat karena anggara sektor public meliputi proses yang kompleks dan bersifat politis (Kahar, Rohman, \& Chariri, 2016)

Church, Kuang, \& Liu (2019) berpendapat bahwa anggaran meliputi 2 tahapan penting yaitu tahap persiapan anggaran dan implementasi anggaran. Tahapan persiapan anggaran akan tercermin dalam RKP desa. Untuk itu, setelah RKP Desa ditetapkan maka tahap berikutnya adalah proses penyusunan APB Desa. Rencana Kegiatan dan Rencana Anggaran Biaya yang telah ditetapkan dalam RKP Desa dijadikan pedoman dalam proses penganggarannya. Anggaran Pendapatan dan Belanja Desa (APB Desa) merupakan rencana anggaran keuangan tahunan Pemerintah Desa yang ditetapkan untuk menyelenggarakan program dan kegiatan yang menjadi kewenangan desa. 
Dalam pelaksanaannya, Pemerintah Desa Tanimulya telah melakukan proses penganggaran dengan urutan yang benar, yakni, anggaran ditetapkan berdasarkan RKP Desa yang telah dirancang di tahap sebelumnya. Selain itu, Pemerintah Desa Tanimulya juga telah menetapkan harga standar sebagai acuan dalam menentukan tarif aktivitas. Akan tetapi, hasil observasi dan wawancara mengidentifikasi beberapa kelemahan seperti: (1) pemahaman Pemerintah Desa masih minim terkait dengan kebijakan anggaran baik dalam penentuan skala prioritas dan peruntukan anggarannya. (2) Terdapat program dan kegiatan yang tidak dianggarkan, tetapi dimasukan ke dalam anggaran. (3) Pengetahuan operator terkait dengan proses input data program ke dalam SIMKEUDES. (4) masih terlihat kelemahan dalam hal perhitungan pajak dikarenakan kurangnya informasi tata cara perhitungan pajak dan pertanggungjawaban kegiatan yang melibatkan pajak.

Setelah diidentifikasi, kelemahan-kelemahan tersebut disampaikan kepada Kepala desa, Sekertaris Desa dan Bendahara Desa Tanimulya. Proses brainstorming dan transfer knowledge dilakukan agar kelemahan-kelemahan tersebut dapat diminimalisir di masa yang akan datang. Selain itu, proses pendampingan penghitungan pajak dilaksanakan untuk mencegah kesalahan perhitungan pajak.

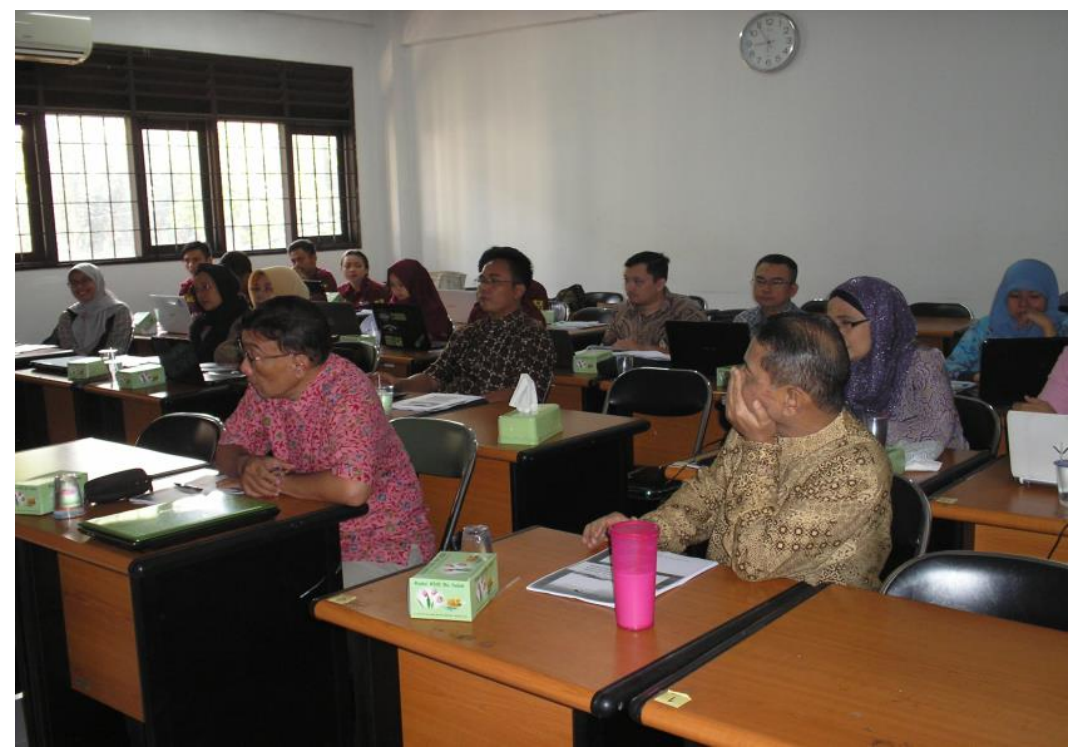

Gambar 3. Pendampingan Proses Penganggaran

\section{Bimbingan teknis perancangan SOP kegiatan desa}

Belum adanya Standar Operasional Prosedur (SOP) yang dibuat baik oleh Pemerintah Desa Tanimulya maupun pemerintah Desa menyebabkan inkonsistensi dalam pelaksanaan kegiatan desa. Untuk itu tim dosen menyampaikan bahwa SOP penting agar alur tugas dan tanggung jawab jelas dan konsisten. SOP sebaiknya dibuat dalam beberapa tahap, dimulai dari SOP kegiatan-kegiatan yang sifatnya penting dan sering berulang. Dalam tahap awal tim dosen membantu dalam proses pembuatan SOP untuk kegiatan pengeluaran insentif untuk RT dan RW (bidang I) dan proses pembuatan rabat beton (bidang II). SOP yang dibakukan diharapkan dapat membantu pemerintah desa dalam mencapai efisiensi dan konsistensi dalam pelaksanaan aktivitas 
desa. Di bawah ini merupakan salah satu contoh SOP yang dibuat bersama dengan Pemerintah Desa.

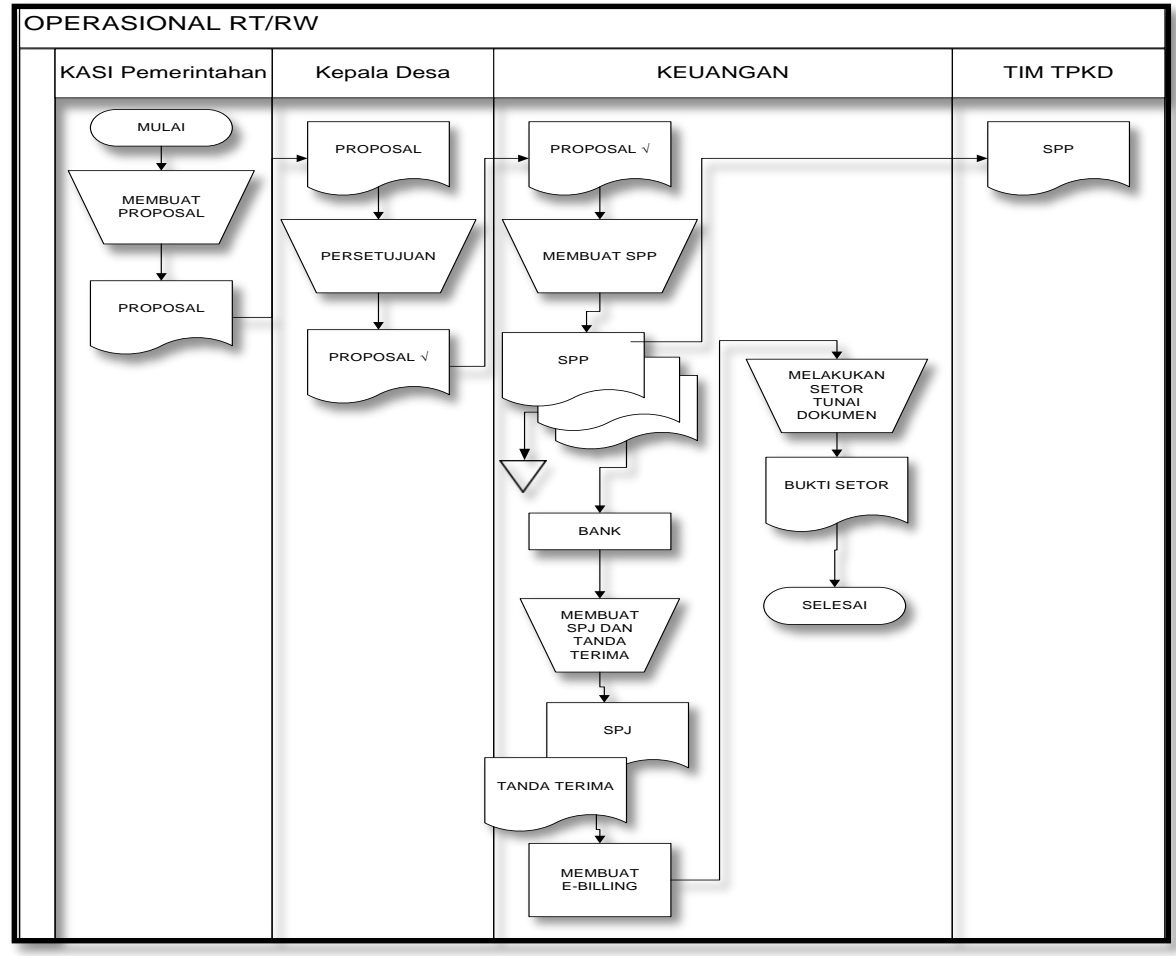

Gambar 4. Hasil SOP Operasional RT dan RW

\section{SIMPULAN}

Berdasarkan hasil pelaksanaan workshop dan bimbingan teknis dapat disimpulkan bahwa pengelola dana desa dapat memahami hubungan antara rencana jangka panjang dengan jangka pendek sehingga memudahkan petugas dalam menentukan anggaran untuk setiap aktivitas yang ada dalam rencana tersebut.

\section{Ucapan Terima Kasih}

Terima kasih kami sampaikan kepada BPKP, LPPM Unjani dan Pemerintah Desa

Tanimulya yang telah bersedia membantu kami dalam kegiatan Pengabdian Masyarakat.

\section{REFERENSI}

Anthony, R., \& Govindarajan, V. (2006). Management Control System (12th ed.). Berkshire, UK: McGraw-Hill Europe.

Berlian Ramadana, C., \& Ribawanto, H. (2013). Keberadaan badan usaha milik desa (BUMDES) Sebagai Penguatan ekonomi desa (Studi di Desa Landungsari, Kecamatan Dau, Kabupaten Malang). Jurnal Administrasi Publik (JAP), 1(6), 10681076. 
Blay, A., Douthit, J., \& Fulmer, B. (2019). Why don't people lie? Negative affect intensity and preferences for honesty in budgetary reporting. Management Accounting Research, 42(May 2018), 56-65. https://doi.org/10.1016/j.mar.2018.05.001

Church, B. K., Kuang, X. (Jason), \& Liu, Y. (Sarah). (2019). The effects of measurement basis and slack benefits on honesty in budget reporting. Accounting, Organizations and Society, 72, 74-84. https://doi.org/10.1016/j.aos.2018.05.005

Kahar, S. H. A., Rohman, A., \& Chariri, A. (2016). Participative budgeting, budgetary slack and job satisfaction in the public sector. Journal of Applied Business Research, 32(6), 1663-1674. https://doi.org/10.19030/jabr.v32i6.9814

Menteri Dalam Negeri Republik Indonesia, I. Peraturan Menteri Dalam Negeri Republik Indonesia Nomor 114 Tahun 2014 (2014). Indonesia.

Pemerintah Republik Indonesia. Peraturan Menteri Desa, Pembangunan Daerah Tertinggal, dan Transmigrasi Nomor 5 Tahun 2015 Tentang Penetapan Prioritas Penggunaan Dana Desa Tahun 2015 (2015). Indonesia.

Pemerintah Republik Indonesia. Permenkeu No.93 Tahun 2015 Tentang Tata Cara Pengalokasian, Penyaluran, Penggunaan, Pemanfaatan Evaluasi Dana Desa (2015). Indonesia.

Soler, M. A. R. K., Cocozza, J. J., \& Henry, A. L. A. N. (2013). Providing and receiving technical assistance: Lessons from models for change. Chicago, Illinoi, US: Policy Research, Inc.

Suralim, G., Tarigan, J., \& Hatane, S. E. (2018). Linking budgetary participation to budgetary slack: An Indonesia perspective. International Journal of Engineering and Technology, 7(4.38), 837-841.

\section{Copyright and License}

This is an open access article distributed under the terms of the Creative Commons Attribution 4.0 International License, which permits unrestricted use, distribution, and reproduction in any medium, provided the original work is properly cited.

(C) 2020 Dwi Indah Lestari, Muhammad Ridwan Mustafa, Muhammad Anggionaldi. 